\title{
INTENSITAS SERANGAN AKIBAT HAMA PEMAKAN DAUN SETELAH APLIKASI EKSTRAK DAUN JERUK NIPIS (Citrus aurantifolia (Cristm.) Swingle) PADA TANAMAN SAWI (Brassica juncea L.)
}

\author{
Faradilla Cyndy Dumanauw ${ }^{1)}$, Henny Lieke Rampe ${ }^{\text {() }}$, Eva Lienneke Baideng ${ }^{\text {1) }}$ \\ ${ }^{1)}$ Program Studi Biologi, FMIPA Universitas Sam Ratulangi Manado \\ e-mail : Faradilladumanauw@gmail.com; Hennyrampe@unsrat.ac.id ; Eva.baideng@yahoo.co.id
}

\begin{abstract}
ABSTRAK
Penelitian ini bertujuan untuk mengevaluasi intensitas serangan akibat hama pemakan daun setelah aplikasi ekstrak daun jeruk nipis pada tanaman sawi. Penelitian ini dilaksanakan di lahan percobaan di Kelurahan Lansot Kecamatan Tomohon Selatan Kota Tomohon pada bulan Desember 2018 Februari 2019. Penelitian ini menggunakan metode eksperimen rancangan acak lengkap (RAL) yang terdiri atas 5 perlakuan konsentrasi ekstrak daun jeruk nipis yaitu J0 (kontrol), J1 $=100 \mathrm{~g}$ ekstrak daun $/ \mathrm{L}, \mathrm{J} 2=200 \mathrm{~g}$ ekstrak daun/L, J3 = $300 \mathrm{~g}$ ekstrak daun/L, dan J4 = $400 \mathrm{~g}$ ekstrak daun $/ \mathrm{L}$. Parameter yang diamati yaitu intensitas serangan akibat hama pemakan daun. Hasil penelitian menunjukkan bahwa pemberian ekstrak daun jeruk nipis berpengaruh nyata terhadap intensitas serangan pada tanaman sawi dan konsentrasi ekstrak daun jeruk nipis yang dapat menekan serangan hama pemakan daun yaitu konsentrasi perlakuan J3 (300 g ekstrak).
\end{abstract}

Kata kunci : Sawi (Brassica juncea L.), hama pemakan daun, jeruk nipis (Citrus aurantifolia)

\section{THE ATTACK INTENSITY DUE TO LEAF-EATING PESTS AFTER APPLICATION OF LIME (Citrus aurantifolia (Cristm.) Swingle) LEAF EXTRACT ON MUSTARD PLANTS (Brassica juncea L.).}

\begin{abstract}
This study is aimed to evaluate the intensity of the attacks due to leaf-eating pests after the application of lime leaf extract on mustard plants. This research was carried out on experimental fiel in Lansot Sub-District, South Tomohon District, Tomohon City in December 2018 - February 2019. This study used a completely randomized design consisting of 5 treatments of lime leaf extract concentrations, namely J0 (Control), J1 $=100 \mathrm{~g}$ leaf extract $/ \mathrm{L}, \mathrm{J} 2=200 \mathrm{~g}$ leaf extract $/ \mathrm{L}$ ), J3 = 300 $\mathrm{g}$ leaf extract/ $\mathrm{L}$, and $\mathrm{J} 4=400 \mathrm{~g}$ leaf extract $/ \mathrm{L}$. The intensity of the attack was observed based on the area of leaf damaged by pest. The results showed that the application of lime leaf extract significantly affected the intensity of attacks on mustard plants and the concentration of lime leaf extract which was able to suppress leaf-eating pests which was the highest in the $\mathrm{J} 3$ treatment $(300 \mathrm{~g}$ extract).
\end{abstract}

Keywords: Mustard (Brassica juncea L.), leaf-eating pests, lime (Citrus aurantifolia).

Article History:

Received: July 11, 2019

Accepted: July 24, 2019

Published: July 25, 2019

\section{PENDAHULUAN}

Sawi (Brassica juncea L.) merupakan tanaman semusim yang dapat tumbuh di sembarang tempat, baik yang beriklim panas maupun dingin dengan ketinggian 5-1.200 m dpl. Tanaman sawi biasanya dibudidayakan di daerah dengan ketinggian $100-500 \mathrm{~m} \mathrm{dpl}$, dengan kondisi tanah gembur, banyak mengandung humus, subur dan drainasenya baik (Edi dan Yusri, 2010).

Tanaman sawi termasuk suku Brassicaceae mempunyai peran penting untuk kesehatan manusia dan juga memiliki nilai 
ekonomi sebagai sumber pendapatan bagi petani. Di Indonesia kebutuhan sawi semakin tinggi seiring dengan kesadaran manusia akan pentingnya sawi sebagai sumber gizi. Laju pertumbuhan penduduk yang semakin meningkat membuat permintaan produksi semakin tinggi khususnya tanaman sawi. Untuk memenuhi kebutuhan masyarakat maka perlu dilakukan peningkatan produksi (Haryanto et al., 2007).

Dalam budidaya tanaman sawi adanya hama dan penyakit menyebabkan produksi sawi menurun. Menurut Winasa dan Herlinda (2003), hama utama tanaman sawi adalah dari ordo Lepidoptera yaitu ulat daun (Plutella xylostella), ulat krop (Crocidolomia binotalis) dan ulat grayak (Spodoptera litura). Untuk menanggulangi adanya hama, upaya yang dilakukan petani adalah dengan menggunakan pestisida sintetik.

Saat ini penggunaan pestisida sintetik dianggap sebagai cara praktis oleh petani untuk mencegah atau menghambat serangan hama/penyakit bagi tanaman. Penggunaan pestisida oleh petani tidak sesuai dengan takaran dosis yang dianjurkan sehingga memberikan dampak buruk bagi lingkungan, dan organisme hidup. Penggunaan pestisida sintetik memiliki dampak negatif terhadap komponen ekosistem lainnya seperti terbunuhnya musuh alami, resurgensi dan resistensi hama serta pencemaran lingkungan. Berdasarkan data World Health Organization (WHO) setiap tahunnya di seluruh dunia diperkirakan sekitar 20.000 orang meninggal akibat keracunan pestisida dan sekitar 5.000 10.000 orang mengalami dampak dari keracunan pestisida tersebut seperti kanker, cacat tubuh, penyakit liver, dan dari angka tersebut yang terbanyak terjadi di negara berkembang (Ipmawati et al., 2016).

Untuk meminimalisir penggunaan pestisida sintetik maka salah satu cara yang dilakukan ialah dengan menggunakan pestisida nabati. Menurut Saenong (2016), pestisida nabati ialah hasil ekstrak dari bagian tertentu tumbuhan yang mengandung bahan aktif berasal dari tumbuhan dan berpotensi untuk mengendalikan hama pada tanaman. Pestisida nabati mudah terurai di alam dan tidak membahayakan bagi lingkungan maupun bagi manusia karena berasal dari tumbuhan. Sesuai dengan program pemerintah dalam hal perlindungan tanaman menerapkan teknik Pengendalian Hama Terpadu sesuai dengan
Inpres No. 3 Tahun 1998, maka perlu dikembangkan pestisida nabati yang merupakan produk alam yang bersifat ramah lingkungan dan tidak menimbulkan dampak negatif ataupun residu (Kardinan, 2011).

Kardinan (2011), menyatakan ciri-ciri tanaman yang dapat digunakan sebagai bahan dasar pestisida nabati adalah : 1) Biasanya dijadikan sebagai tanaman obat baik bagi manusia maupun hewan, 2) Tidak terganggu atas kehadiran Organisme Pengganggu Tanaman (OPT) di sekitarnya, dan 3) Biasanya mengeluarkan aroma khas. Senyawa yang berpotensi pestisida nabati dapat bersifat sebagai biotoksin, pencegah makan (antifeedant), penolak (repellent) dan pengganggu alami, baik yang diperoleh dari tumbuhan maupun jasad renik yang disebut sebagai pestisida biorasional (biorational pesticides) (Rachmawati dan Eli, 2009).

Penelitian yang dilakukan oleh Kasi (2012) diperoleh hasil bahwa ekstrak tanaman daun jeruk nipis mengandung beberapa metabolit sekunder yaitu limonoid yang bersifat sebagai antifeedant, minyak atsiri yaitu senyawa limonen sebagai repellent, dan saponin yang menjadi racun pada saluran pencernaan serangga. Ekstrak daun jeruk nipis dapat digunakan sebagai bionsektisida untuk mengatasi hama walang sangit pada tanaman padi. Kandungan senyawa limonoida paling tinggi pada biji yaitu $927 \mu \mathrm{g} / 100 \mathrm{mg}$, daun yaitu $36,6 \mu \mathrm{g} / 100 \mathrm{mg}$, pada bagian kulit 2,5 $\mu \mathrm{g} / 100 \mathrm{mg}$, dan pada buah yaitu 0,7 $\mu \mathrm{g} / 100 \mathrm{mg}$. Konsentrasi ekstrak daun jeruk nipis sebesar $250 \mathrm{~g} / \mathrm{l}$ dapat mematikan ratarata 9 dari 10 hama walang sangit pada tanaman padi (Gunawan dan Mulyani, 2004).

Hama serangga herbivora yang menyerang tanaman holtikultura sangat bervariasi tergantung dari jenis spesies dan faktor abiotik, demikian juga untuk hama tanaman sawi. Aplikasi ekstrak daun jeruk nipis akan mempengaruhi perkembangan hama serangga herbivora termasuk intensitas serangannya. Berdasarkan informasi tersebut maka akan dilakukan penelitian mengenai intensitas serangan akibat hama pemakan daun setelah aplikasi ekstrak daun jeruk nipis pada tanaman sawi.

Penelitian ini bertujuan untuk mengevaluasi intensitas serangan akibat hama pemakan daun setelah aplikasi ekstrak daun jeruk nipis (Citrus aurantifolia) pada tanaman sawi (Brassica juncea L.). 


\section{BAHAN DAN METODE}

\section{Tempat dan Waktu Penelitian}

Penelitian dilaksanakan di lahan percobaan di Kelurahan Lansot Kecamatan Tomohon Selatan Kota Tomohon dan dilaksanakan pada bulan Desember 2018 Februari 2019.

\section{Metode Penelitian}

Penelitian ini menggunakan Rancangan Acak Lengkap (RAL) dengan 3 kali ulangan yang terdiri atas 5 perlakuan konsentrasi ekstrak daun jeruk nipis sebagai berikut : J0 (kontrol), J1 = $100 \mathrm{~g}$ ekstrak daun $/ \mathrm{L}, \mathrm{J} 2=200 \mathrm{~g}$ ekstrak daun $/ \mathrm{L}, \mathrm{J} 3=300 \mathrm{~g}$ ekstrak daun/L, , dan $\mathrm{J} 4=400 \mathrm{~g}$ ekstrak daun/L.

\section{Persiapan media tanam dan penyemaian benih sawi}

Dibuat 15 bedengan dengan ukuran panjang $100 \mathrm{~cm}$ dan lebar $50 \mathrm{~cm}$. Selanjutnya penentuan perlakuan berdasarkan undian pada bedengan. Setiap bedengan dibuat 8 lubang tanam dengan jarak antara lubang tanam 25 $\mathrm{cm}$. Benih sawi jenis Espana direndam dalam air selama 1 jam, kemudian disemai dibedengan yang telah dipersiapkan sebanyak 5 benih per lubang tanam, dan ditutup dengan tanah setebal 0,5 cm (Samadi, 2017).

\section{Penjarangan Benih}

Bibit sawi yang sudah berumur 14 hari setelah tanam (HST), dilakukan penjarangan yaitu dengan cara mencabut benih dan menyisakan 1 tanaman dalam setiap lubang tanam.

\section{Pemeliharaan Tanaman Sawi}

Pemeliharaan tanaman sawi yaitu dengan melakukan penyiraman tanaman, penyiangan gulma dan pemberian pupuk. Untuk pemupukkan diberi pupuk pada tiap bedeng yaitu KCL $16 \mathrm{~g}$, TSP $24 \mathrm{~g}$, dan Urea 32 g. Pemupukan dilakukan pada saat tanaman sawi berumur 14 HST dan 28 HST.

\section{Pembuatan Ekstrak Daun Jeruk Nipis}

Daun jeruk nipis diambil dari Desa

Kaleosan Kecamatan Kalawat. Pembuatan ekstrak daun jeruk nipis dengan cara daun dicuci bersih dengan air mengalir, lalu dikering-anginkan. Untuk perlakuan (J1), daun sebanyak $100 \mathrm{~g}$ dipotong sekitar $2 \mathrm{~cm}$ kemudian ditambahkan aquades dan diblender. Setelah bahan tanaman halus kemudian disaring, ampas selanjutnya diblender kembali dan disaring sampai yang tersisa adalah serat tanaman. Supernatan digenapkan menjadi $1 \mathrm{~L}$ dengan air, kemudian ditambahkan sabun colek dengan konsentrasi 1 gram sabun untuk 1 liter ekstrak daun jeruk nipis. Untuk J2, J3, dan J4 prosedurnya sama hanya berat daunnya yang berbeda yaitu $\mathrm{J} 2$ sebanyak 200 g, J3 sebanyak $300 \mathrm{~g}$ dan J4 sebanyak $400 \mathrm{~g}$ daun jeruk nipis.

\section{Aplikasi Ekstrak}

Aplikasi ekstrak daun jeruk nipis sesuai perlakuan dengan cara menyemprotkan konsentrasi ekstrak yang telah disiapkan sesuai perlakuan pada semua permukaan bagian tubuh tanaman. Aplikasi ekstrak dilakukan setiap 10 hari yaitu pada saat tanaman berumur 16 HST, 26 HST dan 36 HST.

\section{Pengamatan}

Pengamatan dilaksanakan pada saat tanaman berumur 42 hari setelah tanam (HST). Parameter yang diamati yaitu intensitas serangan akibat hama pemakan daun yaitu dengan menggunakan rumus yang dikemukakan oleh Natawigena (1982) yang telah dimodifikasi adalah sebagai berikut :

$$
\mathrm{P}=\frac{a}{b} \times 100 \%
$$

Dimana:

$\mathrm{P}=$ Intensitas serangan

$\mathrm{a}=$ Luas daun yang diserang

$\mathrm{b}=$ Luas daun yang tanaman yang diamati

Millimeter block digunakan untuk pengukuran a dan $b$, dan untuk mengetahui kategori serangan oleh hama berdasarkan Tabel 1 (Natawigena, 1982).

\section{Analisis Data}

Data yang diperoleh dianalisis dengan Analisis varians (ANAVA), dan dilanjutkan dengan uji Beda Nyata Terkecil (BNT) pada taraf 0,05 (Hanafifah, 2004). 
Tabel 1. Penentuan skala tiap kategori serangan

\begin{tabular}{rcc}
\hline Nilai & Presentasi & $\begin{array}{c}\text { Kategori } \\
\text { Serangan }\end{array}$ \\
Skala & & Normal \\
$\mathbf{0}$ & - & Ringan \\
$\mathbf{1}$ & $0-25$ & Sedang \\
$\mathbf{2}$ & $>25-50$ & Berat \\
$\mathbf{3}$ & $>50-75$ & Sangat berat \\
$\mathbf{4}$ & $>75$ & \\
\hline
\end{tabular}

\section{HASIL DAN PEMBAHASAN}

Data hasil perhitungan rerata intensitas serangan dari setiap tanaman sawi untuk setiap ulangan disajikan pada Tabel 2.

Tabel 2. Rerata Intensitas Serangan Hama Pemakan Daun pada Tanaman Sawi

\begin{tabular}{clllll}
\hline $\begin{array}{c}\text { Perla- } \\
\text { kuan }\end{array}$ & \multicolumn{3}{c}{ Ulangan } & $\begin{array}{c}\text { Jum- } \\
\text { lah }\end{array}$ & $\begin{array}{l}\text { Rerata(\%) } \\
\pm \text { SD }\end{array}$ \\
\cline { 2 - 4 } & 1 & 2 & 3 & & \\
\hline J0 & 21,39 & 20,92 & 27,99 & 70,30 & $23,43 \pm 3,95$ \\
J1 & 17,05 & 20,39 & 14,77 & 52,21 & $17,40 \pm 2,83$ \\
J2 & 11,20 & 10,25 & 10,03 & 31,48 & $10,49 \pm 0,62$ \\
J3 & 4,40 & 7,37 & 5,46 & 17,23 & $5,74 \pm 1,51$ \\
J4 & 2,28 & 1,62 & 1,76 & 5,66 & $1,89 \pm 0,35$ \\
\hline
\end{tabular}

Penelitian ini menggunakan daun jeruk nipis dengan konsentrasi ekstrak yang berbeda. Berdasarkan hasil pengamatan diperoleh rerata intensitas serangan pada perlakuan J0 (Kontrol) menunjukkan nilai intensitas serangan tertinggi yaitu $23,43 \%$, diikuti perlakuan J1 yaitu $17,40 \%$, perlakuan $\mathrm{J} 2$ yaitu $10,49 \%$, J3 yaitu $5,74 \%$, dan J4 yaitu $1,89 \%$.

Data hasil analisis varian intensitas serangan hama pemakan daun pada tanaman sawi setelah aplikasi ekstrak daun jeruk nipis perhitungannya disajikan pada Tabel 3 .

Tabel 3. Hasil Analisis Varian Intensitas Serangan Hama Pemakan Daun pada Tanaman Sawi setelah Aplikasi Ekstrak Daun Jeruk Nipis

\begin{tabular}{llllll}
\hline SK & DB & JK & KT & F & F \\
& & & & Hitung & $\mathbf{0 , 0 5}$ \\
\hline Perlakuan & 4 & 910.19 & 227.55 & $43.10^{*}$ & 3.48 \\
Galat & 10 & 52.78 & 5.28 & & \\
Total & 14 & & & & \\
\hline Ket & & & &
\end{tabular}

Ket $*$ berbeda nyata
Berdasarkan Tabel 3, diperoleh nilai $\mathrm{F}$ hitung yaitu 43.10 lebih besar dari nilai $\mathrm{F} 0,05$ yaitu 3,48. Hal ini menunjukkan bahwa pemberian ekstrak daun jeruk nipis berpengaruh nyata terhadap intensitas serangan hama pemakan daun pada tanaman sawi.

Data hasil uji beda nyata terkecil (BNT) perhitungannya ditunjukkan pada Tabel 4.

Tabel 4. Hasil uji Beda Nyata Terkecil (BNT) Intensitas Serangan Akibat Hama Pemakan Daun setelah Aplikasi Ekstrak Daun Jeruk Nipis

\begin{tabular}{rrr}
\hline Perlakuan & Rerata & $\begin{array}{c}\text { Notasi BNT } \\
\mathbf{0 , 0 5}(=\mathbf{0 . 2 5})\end{array}$ \\
\hline J0 & 23.43 & $\mathrm{a}$ \\
J1 & 17.40 & $\mathrm{~b}$ \\
J2 & 10.49 & $\mathrm{c}$ \\
J3 & 5.74 & $\mathrm{~d}$ \\
J4 & 1.89 & $\mathrm{~d}$ \\
\hline
\end{tabular}

Ket. Huruf yang berbeda dalam satu kolom menunjukkan berbeda nyata

Jeruk nipis adalah salah satu tanaman yang dapat digunakan sebagai insektisida nabati karena mengandung metabolit sekunder berupa senyawa limonoid yang merupakan senyawa khas golongan terpenoid berfungsi sebagai insektisida dan bertindak sebagai racun perut (Huda, 2013). Hasil penelitian yang dilakukan oleh Kasi (2012), Huda (2013), dan Sakka (2018) menunjukan bahwa ekstrak daun jeruk nipis mengandung senyawa metabolit sekunder seperti alkaloid, flavonoid, limonoid, minyak atsiri, saponin dan tanin.

Berdasarkan pengamatan pada Tabel 1, diperoleh hasil bahwa penggunaan ekstrak daun jeruk nipis pada perlakuan $400 \mathrm{~g}$ ekstrak (J4) menunjukan sebagai konsentrasi ekstrak daun jeruk nipis yang paling baik dalam mengurangi hama ulat daun pada tanaman sawi. Hal ini sejalan dengan hasil penelitian Mawuntu (2016) yang menyatakan bahwa semakin tinggi konsentrasi ekstrak yang digunakan maka semakin tinggi pula angka mortalitas hama yang menyerang tanaman.

Pada pengamatan 14 hari setelah tanam (HST) ditemui hama ulat grayak dan ulat tritip dalam tanaman sawi seperti yang ditunjukkan pada Gambar 1 dan Gambar 2. Hama ini menyebabkan kerusakan daun seperti berlubang-lubang kecil dan membuat daun menjadi transparan seperti yang 
ditunjukkan pada Gambar 3. Selanjutnya pada pengamatan 21 hari setelah tanam (HST) ditemui hama ulat krop seperti yang disajikan pada Gambar 4. Hama ini menyebabkan kerusakan daun seperti daun menjadi berlubang dan terdapat bercak kotoran pada daun tanaman sawi. Dapat dilihat bahwa sekelompok ulat krop menyerang tanaman sawi. Hal ini sejalan dengan pendapat yang dikemukakan oleh Ahmad (2007), yang menyatakan ulat krop adalah hama yang sangat rakus dan menyerang secara berkelompok.

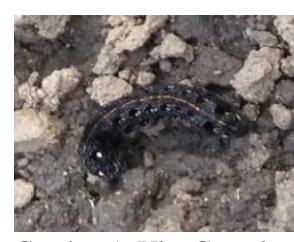

Gambar 1. Ulat Grayak (Spodoptera litura)

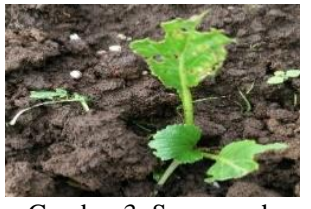

Gambar 3. Serangan hama ulat krop
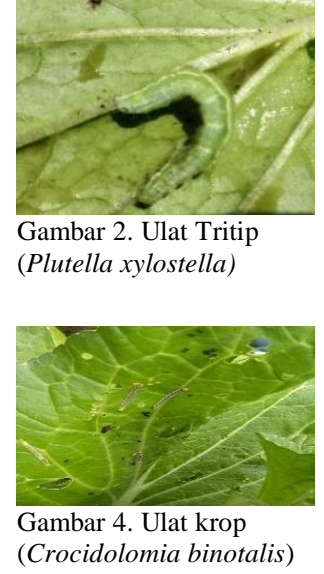

Setelah aplikasi pertama (16 HST) daun jeruk nipis secara perlahan intensitas serangan hama pemakan daun pada tanaman sawi mulai mengalami perubahan. Setelah dilakukan aplikasi kedua (26 HST) dan ketiga (36 HST), kerusakan daun tanaman sawi mulai berkurang. Hal ini dikarenakan ekstrak daun jeruk nipis mengandung senyawa metabolit sekunder seperti seperti alkaloid, flavonoid, limonoid, minyak atsiri, saponin dan tanin.

Pestisida yang berperan dalam jeruk nipis ini tergolong metabolit sekunder (Pandiangan, 2009), juga tergolong Alkaloid. Alkaloid pada ekstrak daun jeruk nipis berpengaruh dalam proses perkembangan serangga. Serangga akan terganggu pada proses pergantian kulit, ataupun proses perubahan dari telur menjadi larva, larva menjadi pupa, atau dari pupa menjadi dewasa (Huda, 2013). Karimah (2006) dan Huda (2013) menyatakan bahwa flavonoid pada ekstrak daun jeruk nipis berperan sebagai salah satu inhibitor dalam pernafasan, dan menghambat tiga hormon utama dalam serangga yaitu hormon otak, hormon edikson, dan hormon pertumbuhan.
Limonoid pada ekstrak daun jeruk nipis bersifat sebagai antifeedant, zat pengatur tumbuh dan zat toksik pada kutu beras, larvasida, antimikroba, penolak serangga, dan penghambat reproduksi. Limonoid dapat masuk ke dalam tubuh insekta melalui kulit atau dinding tubuh dengan cara osmosis karena kulit atau dinding tubuh serangga bersifat permeabel terhadap senyawa yang dilewati. Limonoid tersebut akan masuk ke sel-sel epidermis yang selalu mengalami pembelahan dalam proses pergantian kulit. Sebagai racun perut senyawa limonoid masuk ke pencernaan melalui makanan yang telah terkontaminasi ekstrak yang termakan. Senyawa limonoid akan masuk ke dalam tubuh serangga melalui tanaman yang telah diaplikasikan ekstrak lalu masuk ke pencernaan, diserap oleh dinding usus dan beredar dengan darah yang kemudian akan mengganggu metabolisme tubuh serangga sehingga menyebabkan serangga kekurangan energi untuk aktivitas hidupnya dan mengakibatkan serangga kejang dan akhirnya mati (Huda, 2013).

Minyak atsiri pada estrak daun jeruk nipis adalah senyawa limonen yang bersifat sebagai repellent. Aroma dari minyak atsiri tersebut tidak disukai oleh hama, sehingga hama tidak akan memakan tanaman sawi yang telah diaplikasikan ektrak daun jeruk nipis (Kasi, 2012). Kasi (2012) menyatakan bahwa saponin pada ekstrak daun jeruk nipis menimbulkan busa seperti pada sabun ketika dikocok sehingga bagian tanaman yang telah diaplikasikan dengan ekstrak daun jeruk nipis dimakan oleh hama, maka saponin akan bereaksi dengan air di dalam tubuh dan menjadi racun yang mematikan bagi hama tersebut. Senyawa saponin juga memiliki peran dalam gangguan terhadap perkembangan dan gangguan pergantian kulit (Huda, 2013). Sejalan dengan penenlitian yang dilakukan oleh Chaieb (2010) dalam Gogok (2013) yang menyatakan saponin menghambat pengelupasan kulit larva sehingga larva tidak dapat berkembang ke fase berikutnya.

Tanin dalam ekstrak daun jeruk nipis berfungsi menghalangi serangga dalam mencerna makanan dan akhirnya mengganggu pertumbuhan serangga karena tannin akan mengendapkan protein dalam sistem pencernaan yang diperlukan serangga untuk pencernaan. Hal ini mengakibatkan proses 
penyerapan protein dalam sistem pencernaan menjadi terganggu (Huda,2013).

Berdasarkan pengamatan diperoleh bahwa pada perlakuan J0, J1, J2, J3, dan J4 termasuk dalam kategori serangan ringan yaitu > 0-25, sesuai tabel 4. Hal ini dikarenakan cuaca pada saat penelitian dalam kondisi hujan. Daha (1997) dalam Sumual et al., (2014) menyatakan bahwa curah hujan mempengaruhi perkembangan populasi larva. Populasi larva jauh lebih tinggi pada musim kemarau daripada musim hujan.

\section{KESIMPULAN DAN SARAN}

\section{Kesimpulan}

Pemberian ekstrak daun jeruk nipis berpengaruh nyata terhadap intensitas serangan akibat hama pemakan daun setelah aplikasi ekstrak daun jeruk nipis pada tanaman sawi. Konsentrasi ekstrak daun jeruk nipis yang dapat menekan serangan hama pemakan daun yaitu perlakuan J3 (300 g ekstrak).

\section{Saran}

Perlu dilakukan penelitian lebih lanjut untuk melihat kepadatan populasi hama pemakan daun pada tanaman sawi dengan menggunakan ekstrak daun jeruk nipis.

\section{DAFTAR PUSTAKA}

Ahmad, H. 2007. Laporan Hama Ulat Krop Crocidolomia binotalis pada Kubis Brassica oleracea. IPB e-repository, Bogor.

Chaieb, I. 2010. Saponin as Insecticide: a review. Journal of Plant Protection. 5: 39-50.

Daha, L. 1997. Ekologi Helicoverpa armigera (HUBNER) (Lepidoptera : Noctuidae) pada Pertanaman Tomat. Program Pascasarana, IPB.

Edi dan Yusri. 2010. Budidaya Sawi Hijau. Balai Pengkajian Teknologi Pertanian Jambi, Jambi.

Gunawan, D., dan S, Mulyani. 2004. Ilmu Obat Alam (Farmakognosi) Jilid 1. Penebar Swadaya, Jakarta.
Gogok, S. 2013. Uji Toksisitas Bioinsektisida Ekstrak Metanol Buah Bintaro Cerbera odollam L. terhadap Mortalitas Ulat Grayak Spodoptera litura pada Pakan Daun Tomat [skripsi]. FKIP USD, Yogyakarta.

Hanafifah, A.K. 2004. Rancangan Percobaan. Edisi Ketiga. Raja Grafindo Persada, Jakarta.

Haryanto, E., T. Suhartini., E. Rahayu., H. Sunarjo. 2007. Sawi dan Selada. Penebar Swadaya, Jakarta.

Huda, Z.M. 2013. Efektivitas Ekstrak Jeruk Nipis Citrus aurantifolia terhadap Kumbang Beras Sitophilus sp dan Kualitas Nasi [skripsi]. FTK UIN Raden Intan, Lampung.

Ipmawati, P.A., O. Setiani., Y.H. Danudainti. 2016. Analisis Faktor-Faktor Resiko yang Mempengaruhi Tingkat Keracunan Pestisida pada Petani di Desa Jati, Kecamatan Sawangan , Kabupaten Magelang, Jawa Tengah. Jurnal Kesehatan Masyarakat 4: 427435.

Kardinan, A. 2011. Penggunaan Pestisida Nabati sebagai Kearifan Lokal dalam Pengendalian Hama Tanaman menuju Sistem Pertanian Organik. Jurnal Pengembangan Inovasi Pertanian 4(4): 262-278.

Karimah, L. N. 2006. Uji Aktifitas Larvasida Ekstrak Etanol 96\% Biji Mahoni Swietenia mahagoni jacq Terhadap Larva Nyamuk Anopheles Aconitrus Instar III Serta Profil Kromatografi Lapis Tipisnya. UMS : F.Farmasi.

Kasi,P. D. 2012. Pemanfaatan Ekstrak Daun Jeruk Nipis Citrus aurantifolia sebagai Insektisida Nabati terhadap Hama Walang Sangit Leptocorisa oratorius pada Tanaman Padi. Jurnal Dinamika 3(1): 12-18.

Mawuntu, M. 2016. Efektivitas Ekstrak Daun Sirsak dan Daun Pepaya dalam Pengendalian Plutella xylostella L. (Lepidoptera; Yponomeutidae) pada Tanaman Kubis di Kota Tomohon. Jurnal Ilmiah Sains 16(1): 24-29. 
Natawigena. 1982. Membuat dan Memanfaatkan Pestisida Ramah Lingkungan. Agromedia Pustaka, Jakarta.

Pandiangan, D. 2009. Produksi Metabolit Sekunder Alkaloid Secara in vitro. UNPAD Press, Bandung.

Rachmawati, D. dan K. Eli. 2009. Pemanfaatan Pestisida Nabati untuk Mengendalikan Pengganggu Tanaman. Balai Pengkajian Teknologi Pertanian, Jawa Timur.

Saenong, M. S. 2016. Tumbuhan Indonesia Potensial sebagai Insektisida Nabati untuk Mengendalikan Hama Kumbang Bubuk Jagung Sitophilus sp. Jurnal Litbang Pertanian 35(3): 131-142.

Sakka, L. 2018. Identifikasi Senyawa Alkaloid, Saponin, dan Tanin pada Jeruk Nipis Citrus aurantifolia di Kabupaten Bone Kecamatan Lamuru Menggunakan Metode Infusa. Jurnal Ilmiah Kesehatan Diagnosis 12(6): 670-674.

Samadi, B. 2017. Teknik Budidaya Sawi dan Pak Choy. Pustaka Mina, Depok Timur.

Sumual, S. D., A. N. Pinaria., T. Dantje., dan S.. Susniahti, N., H. Sumento., Sudarjat. 2005. Bahan Ajar Ilmu Hama Tumbuhan. Fakultas Pertanian Universitas Padjajaran, Bandung.

Winasa, I.W, dan S, Herlinda. 2003. Ecology of Diamondback Moth, Plutella xylostella L. Lepidoptera: Yponomeutidae, on Mustard Brassica juncea Coss in Lowland Area of South Sumatera. Proceedings of an International Seminar \& Exhibition; Palembang, 8-9 Desember 2003. Prospectives of Lowland Development in Indonesia. Hlm 1-7. 